\title{
EFFECT OF USING CORNER REINFORCEMENT ON THE STRUCTURAL BEHAVIOUR OF R.C SOLID SLABS
}

\author{
Aly G. Aly , Fayez K. Abd El-SayeD*, \\ M. Hamed Hussein ${ }^{\star \star}$, Zainab Ebraheem Abd El-Shafy ${ }^{\star \star \star}$. \\ and Hamedo Mohamady Abd Elshafy El Nagdy \\ ${ }^{+}$Professor of structural Engineering, King Abdulaziz University. \\ "Professor of structural Engineering, Civil Eng. Dept. Assiut University. \\ ** Associate Professor of structural Engineering, Assiut University. \\ *** Assistant lecturer, Civil Eng. Dept., Assiut University. \\ ${ }^{* * * *}$ B.S.c, Civil Engineering, Assiut University (Currently working in Suez \\ Canal Authority)
}

(Received July 29, 2009 Accepted September 8, 2009).

This research introduces the real behaviour of R.C two-way slab with additional top and bottom corner reinforcement. Such reinforcement contributes in stiffening slabs corner to resist torsional and shear stresses.

For this purpose a numerical studies have been performed to illustrate the effect of such reinforcement on the structural behaviour of R.C slabs .the 3D-FEM model through (ANSYS) software package has been used to accomplish this study, the eight node solid element is used to model the concrete, this element is capable of having plastic deformation, cracking in three orthogonal directions, and crushing which were all taken into consideration. The reinforcement was modelled as a three-dimensional bar element. In this research several parameters have been taken into consideration :(a)percentage of slab main reinforcement; (b) percentage of corner reinforcement as a ratio from the main reinforcement; (c) corner reinforcement spacing;(d)margin beam stiffness ;(e)slab rectangularity.

The results show that the existence of corner reinforcement in R.C two-way slabs improves considerably the structural behaviour of such slabs leading to higher ultimate load and lower values for deflection.

In this research the maximum midspan deflection and the ultimate load carrying capacity were recorded. It has been found for the studied cases that the increase of load carrying capacity is up to (28\%) and the decrease in central deflection of slab is up to (30\%).

From this study it can be found that the distribution of corner reinforcement $(S=7,14,21 \mathrm{~cm})$ and its percentage from the main steel $(43 \%, 72 \%, 100 \%)$ has a significant effect on increasing ultimate load and decreasing the central deflection.

KEYWORDS: Load carrying capacity, central deflection, corner reinforcement, bar intervals.

\section{I - INTRODUCTION}

Using solid slab system for large spans is fraught with difficulties mostly due to increasing the straining actions, deflections which tend to decrease the ultimate load carrying capacity. 


\section{NOTATION}

\begin{tabular}{|c|c|c|c|}
\hline$E_{c}$ & the elastic modulus & $\beta_{t}$ & $\begin{array}{l}\text { shear transfer coefficient for an open } \\
\text { crack }\end{array}$ \\
\hline$f$ & stress at any strain & $\beta_{e}$ & $\begin{array}{l}\text { shear transfer coefficient for a close } \\
\text { crack }\end{array}$ \\
\hline$f_{c}^{\prime}$ & $\begin{array}{l}\text { ultimate compressive strength } \\
\text { of concrete }\end{array}$ & $\delta_{\max }$ & the maximum central deflection \\
\hline$f_{r}$ & modulus of rapture & $\delta_{o}$ & $\begin{array}{l}\text { the maximum central deflection at } \mathrm{A} 2 \\
\text { failure load }\end{array}$ \\
\hline$f_{y}$ & steel yield stress & $\gamma$ & density \\
\hline$k$ & the corner holding-down force & $\varepsilon$ & strain at stress \\
\hline$M_{\delta}$ & torsional moment & $\varepsilon_{o}$ & $\begin{array}{l}\text { strain at the ultimate compressive } \\
\text { strength }\end{array}$ \\
\hline Pcr & first cracking load & $\mu$ & $\begin{array}{l}\text { percentage of corner reinforcement from } \\
\text { the main steel }\end{array}$ \\
\hline$P y$ & first yielding load & $\mu s$ & $\begin{array}{l}\text { percentage of main reinforcement } \\
=\mathrm{As} / \mathrm{Ac}\end{array}$ \\
\hline$R$ & corner reaction & $v$ & Poisson's ratio \\
\hline $\mathrm{g}$ & corner reinforcement spacing & & \\
\hline
\end{tabular}

\section{It is Evident from the Elastic Theory for Slabs Analysis that}

High values of torsional moment occurs at the corner regions and that if the corner of simply supported slab is not held down; it will tend to lift off the support (developing -ve corner reactions) for which reinforcement must be provided at such regions.

Therefore the British Standard Code OF Practice (BSI) [1] states that at corners contained by edges over neither of which the slab is continuous, top and bottom reinforcement should be provided for torsion at the corners of such slabs. Both top and bottom reinforcement should consist of two layers of bars placed parallel to the sides of the slab and extending in these directions for a distance of one-fifth of the shorter span. The area of the bars in each of the four layers, per unit width of the slab, should be threequarter of the area required for the maximum positive moment in the slab Fig. (1-a).

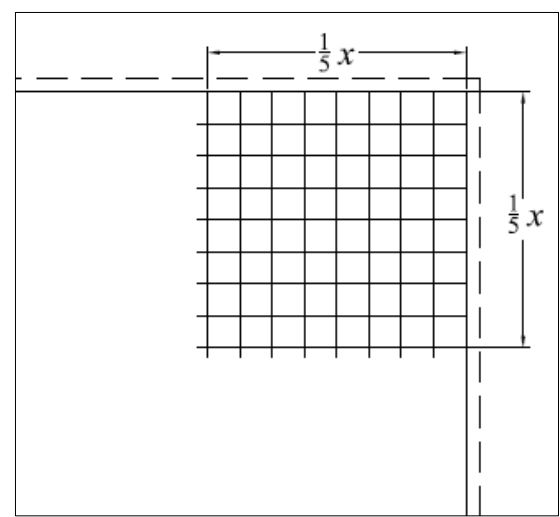

Fig. (1-a): Corner reinforcement according to BSI

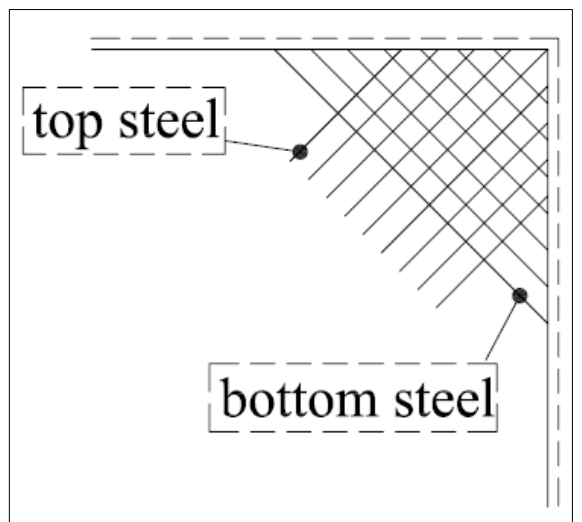

Fig. (1-b): Corner reinforcement according to ACI 
However according to the American concrete institute (ACI-318-02) [2] this reinforcement is to be provided for a distance in each direction from the corner equal to one-fifth the longer span. This reinforcement in both top and bottom of the slab must be sufficient to resist a moment equal to the maximum bending moment per unit length of width in the slab, and it may be placed in a single band parallel to the diagonal in the top of the slab and perpendicular to the diagonal in the bottom of the slab Fig. (1-b), or in two bands parallel to the sides of the slab.

Torsion in simply supported slab: as mentioned before that when loading is applied to a simply supported slab the corners are lifted off their supports. The holdingdown force, can be determined in terms of the load $\boldsymbol{k}$ by means of the elastic theory of slabs [3]. This force is expressed by " $\mathrm{R}$ " where:

$$
R=\rho k
$$

Where the coefficient $\rho$ dependent upon $\eta=l y / l x$

For slabs simply supported on four sides the values of $\rho$ have been given by Marcus and are indicated in the following table.

Table (1)

\begin{tabular}{|r|r|r|r|r|r|r|r|r|r|r|}
\hline$\eta$ & 1.0 & 1.2 & 1.4 & 1.6 & 1.8 & 2.0 & 2.5 & 3.0 & 3.5 & 4.0 \\
\hline$\rho$ & 0.083 & 0.080 & 0.076 & 0.071 & 0.066 & 0.060 & 0.049 & 0.041 & 0.035 & 0.031 \\
\hline
\end{tabular}

Consider Fig. (2-a) in a diagonal plane $\alpha-\alpha$ at a distance $a$ from the corner the force $\mathrm{R}$ produces a moment $R a$ "torsional moment" this moment is distributed over the length $2 a$ where:

$$
M_{\delta}=R a / 2 a=\rho \mathrm{K} / 2
$$

And this" torsional moment" $\left(M_{\delta}\right)$ acts across the plane $\beta-\beta$ Fig (2-b) and produces a tensile stresses at the underside of the slab. Hence it is necessary to provide bottom reinforcement as shown in Fig. (2-b).

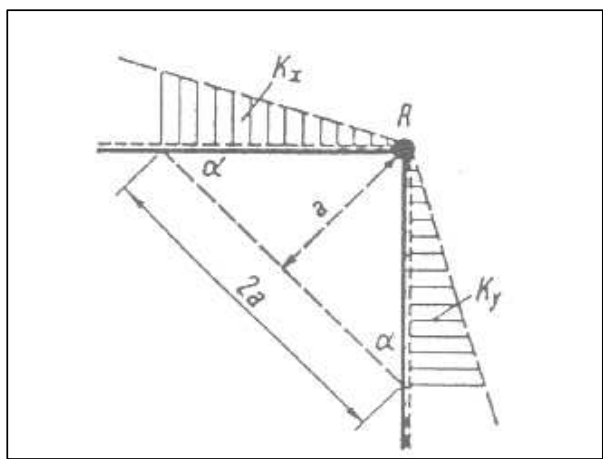

Fig. (2-a): Corner force R acts at corner

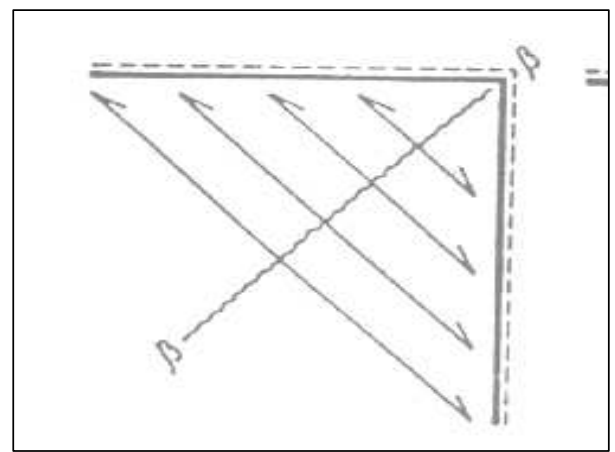

Fig. (2-b): Induced torsional moment $\left(M_{\delta}\right)$ acts across the plane $\beta-\beta$ 


\section{II- VERIFICATION OF ANSYS COMPUTER PROGRAM}

The used computer program has been applied on a well known example $\underline{S l a b}(5 \times 5 \times 0.12$ $\underline{m})$ and the optioned results were in complete agreement with the exact solution obtained by Czernys [4].

\section{II-1-Concrete Constitutive Model}

\section{Solid 65 element:}

Solid65, an eight node solid element, is used to model the concrete with or without reinforcing bars (smeared or discrete reinforcement). The solid element has eight nodes with three degrees of freedom at each node-translation in the nodal $\mathrm{X}, \mathrm{Y}$, and $\mathrm{Z}$ directions. The element is capable of having plastic deformation, cracking in three orthogonal directions, and crushing. The geometry and node locations for this element type are shown in Fig. (3).
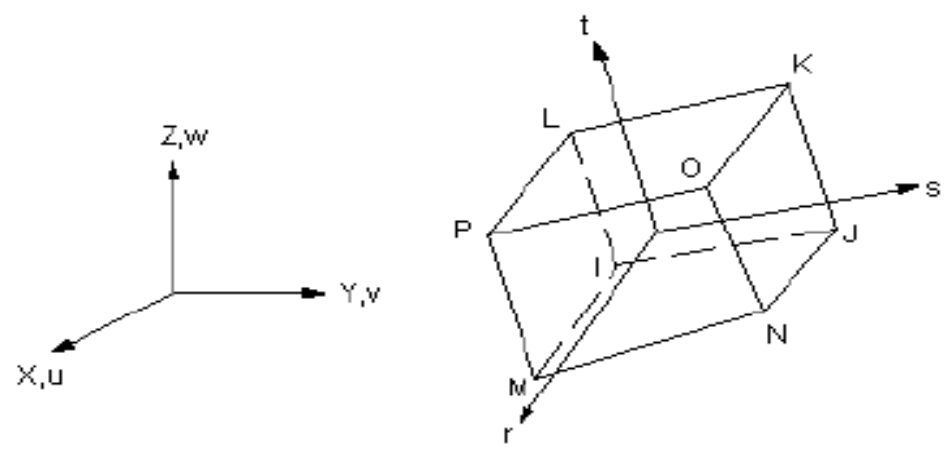

Fig. (3): Solid65-3D reinforced concrete element

\section{The Consideration of Solid65 Element Input Data:}

ANSYS requires input data for material properties of solid65 element as elastic modulus $\left[E_{r}\right]$,Ultimate uniaxial compressive strength $\left[f_{c}\right.$ '], ultimate uniaxial tensile strength [modulus of rapture, $f_{r}$ ] Poisson's ratio $(v)$, density $(\gamma)$, shear transfer coefficient for an open crack $\left(\beta_{t}\right)$, shear transfer coefficient for a close crack $\left(\beta_{c}\right)$ [5], [6], compressive uniaxial stress-strain relationship for concrete.

The elastic modulus of elasticity: is obtained by the pulse velocity method and can be calculated by means of its ultimate concrete compressive strength for each slab model by using Equation (3) ACI_318 [2]

$$
f_{c}{ }^{\prime}=\left[\frac{E{ }_{c}}{4730}\right]
$$

Where:

Ec elastic modulus of concrete in $\mathrm{MPa}\left(\mathrm{MPa}=10.2 \mathrm{~kg} / \mathrm{cm}^{2}\right)$.

$f_{c}^{\prime}$ Ultimate compressive strength of concrete in MPa.

The tensile strength of concrete: is typically $8-15 \%$ of the compressive strength Shah et al. 1995 [7]. 


\section{Stress- strain relation for concrete}

Atypical stress-strain curve for concrete as an example is shown in Fig. (4), Bangash 1989[8]. In compression the stress strain curve for concrete is linearly elastic up to about $30 \%$ of the maximum compressive strength. Above this point the stress increases gradually up to the maximum compressive strength. After it reaches the maximum compressive strength $f_{c u}$ the curve descends into a softening region and eventually crushing failure occurs at an ultimate strain $\varepsilon_{c u}$.

In tension the stress-strain curve for concrete is approximately linearly elastic up to the maximum tensile strength. After this point the concrete cracks and the strength decreases gradually to zero Bangash [8].

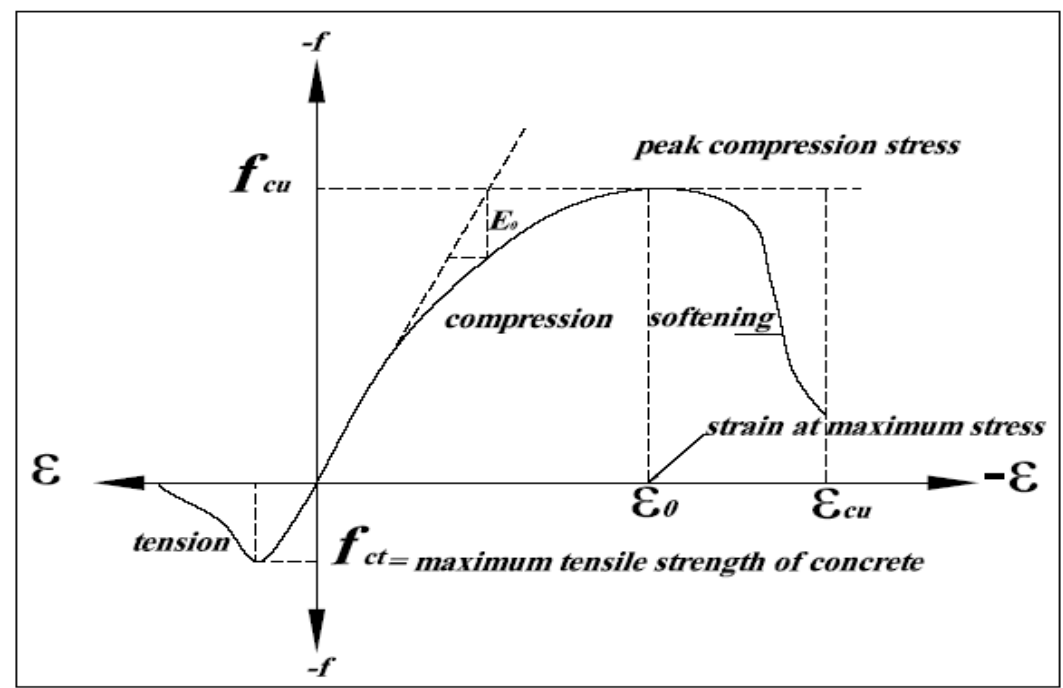

Fig. (4): Typical uniaxial compressive and tensile stress-strain curve for concrete (Bangash 1989).

Ansys program requires the uniaxial stress-strain relation for concrete in compression. Numerical expressions of Desayi and Krishnan 1964 [9] Equation (4) and (5) were used along with Equation (6) Gere and Timoshenko 1997[10] to construct the uniaxial compressive stress-strain curve for concrete in this study.

$$
\begin{aligned}
f & =\frac{E_{C} x \varepsilon}{1+\left(\frac{\varepsilon}{\varepsilon_{0}}\right)} \\
\varepsilon_{0} & =\frac{2 f_{c}^{\prime}}{E_{c}} \\
E_{c} & =\frac{f}{\varepsilon}
\end{aligned}
$$

Where:

$$
\begin{aligned}
& f=\text { stress at any strain } \varepsilon, \text { in } \mathrm{MPa}\left(\mathrm{MPa}=10.2 \mathrm{~kg} / \mathrm{cm}^{2}\right) . \\
& \varepsilon=\text { strain at stress } f
\end{aligned}
$$


$\varepsilon_{\mathrm{o}}=$ strain at the ultimate compressive strength $f_{c}$ ' in $\mathrm{MPa}$

The density $(\gamma)$ and the Poisson's ratio $(v)$, of concrete are considered as $2200 \mathrm{~kg} / \mathrm{m}^{3}$ and 0.20 respectively.

Table (2)

\begin{tabular}{|c|c|c|c|c|c|}
\hline$\left(E_{c}\right) \mathrm{kg} / \mathrm{cm}^{2}$ & $(v)$ & $\left(\beta_{t}\right)$ & $\left(\beta_{c}\right)$ & $\left(f_{r c}\right) \mathrm{kg} / \mathrm{cm}^{2}$ & $\left(f_{c}^{\prime}\right) \mathrm{kg} / \mathrm{cm}^{2}$ \\
\hline $2.617 \mathrm{E}+5$ & 0.2 & 0.2 & 0.5 & 33 & 350 \\
\hline
\end{tabular}

\section{II-2-Reinforcement Constitutive Model}

\section{Reinforcement Consideration:}

In this research reinforcement has been modeled as a discrete reinforcement (Link8) throughout the element (solid65).

Link8 element, the three-dimensional spar element is a uni-axial tensioncompression element with three degrees of freedom at each node: translations in the nodal $\mathrm{X}, \mathrm{Y}$ and $\mathrm{Z}$ directions. As in a pin-jointed structure, no bending of the element is considered. The element is also capable of having plastic deformation, stress stiffening, and large deflection. The geometry, node locations, and the coordinate system for this element are shown in Fig. (5).

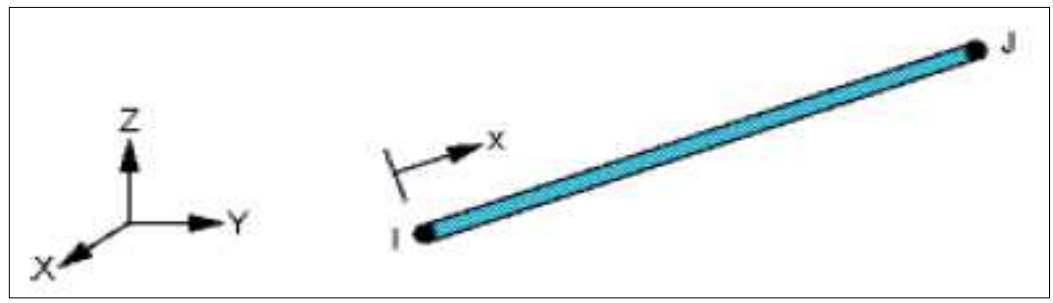

Fig. (5): Link8-3D Spar element.

\section{Material properties for steel reinforcement:}

Steel reinforcement in considered models was constructed with typical grade $36 / 52$. The steel was assumed elastic-perfectly plastic material( Bilinear Isotropic Hardening) and identical in tension and compression.

These options use the von Mises yield criterion with the associated flow rule and isotropic work hardening. Fig. (6) shows stress-strain relationship used in this study.

\section{taking into consideration the following data:}

- Poisson's ratio of 0.3 was used for steel reinforcement in this study Gere and Timoshinko (1997) [8].

- Yield stress $\quad f_{y} 3600 \mathrm{~kg} / \mathrm{m}^{2}$.

\section{III- GEOMETRICAL MODELING}

\section{In all studied cases:-}

- Only one quarter of the model was solved due to symmetry, Fig. (9). 
- The uniform load applied on slabs is taken as a concentrated load at the intermediate point of each element.

- All nodes on slab corners are prevented from translation in X, Y, Z directions for slab beam models.

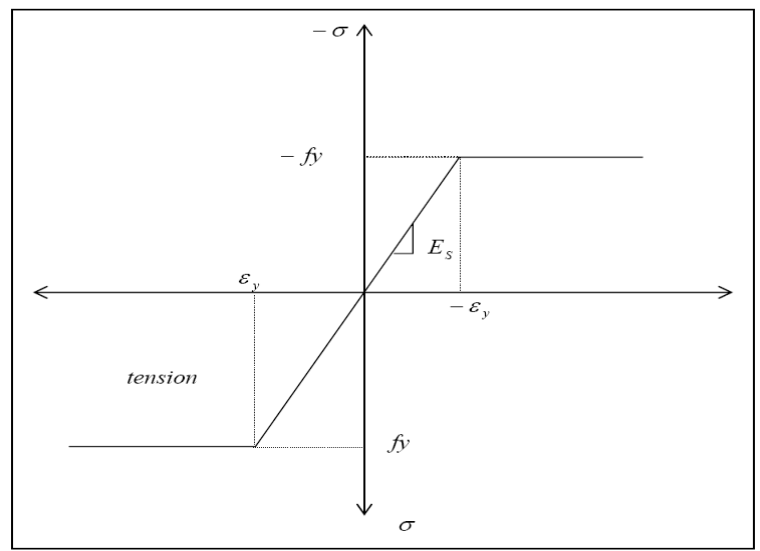

Fig. (6): Steel stress-strain relationship used in this study.

\section{Loads and Boundary Conditions:}

- The supports at the corner nodes were prevented from translation in $\mathrm{X}, \mathrm{Y}, \mathrm{Z}$ $(\mathrm{Uz}=\mathrm{Ux}=\mathrm{Uy}=0$ ) support condition is shown in Fig. (7), Fig. (8) for slab models.

- The pressure applied on slabs is taken as a concentrated load at the intermediate point of each element. Fig. (7) illustrates the applied loading.

- The symmetry boundary conditions were set first. The model being used is Symmetric about two planes. The boundary conditions for both planes of symmetry are shown in Fig. (8).

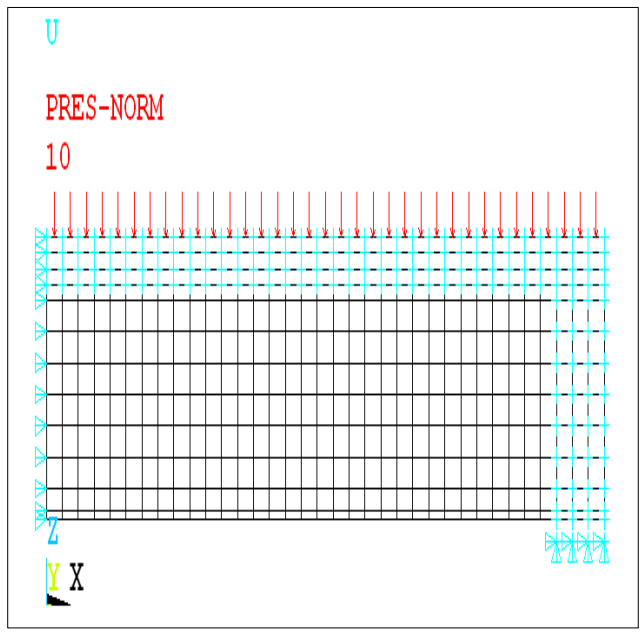

Fig. (7): Pressure on concrete element

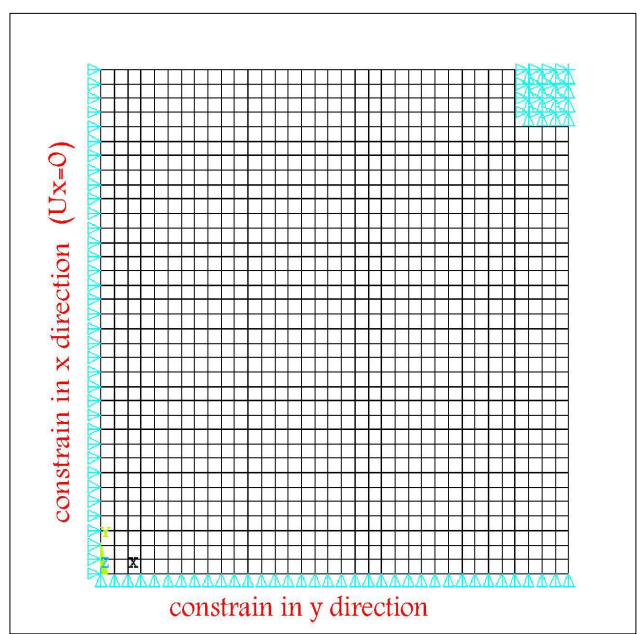

Fig. (8): Boundary Condition for Support (slab beam models) 


\section{Reinforcement Modeling:}

- Slab reinforcement:

Slab has an orthogonal reinforcement in $\mathrm{x}$ and $\mathrm{y}$ direction

- Beam reinforcement:

○ Main reinforcement $8 \# 22 \mathrm{~mm}$, stirrups hunger $4 \# 16 \mathrm{~mm}$, side bars 4\#12mm and stirrups \#8mm@10cm Fig. (9).

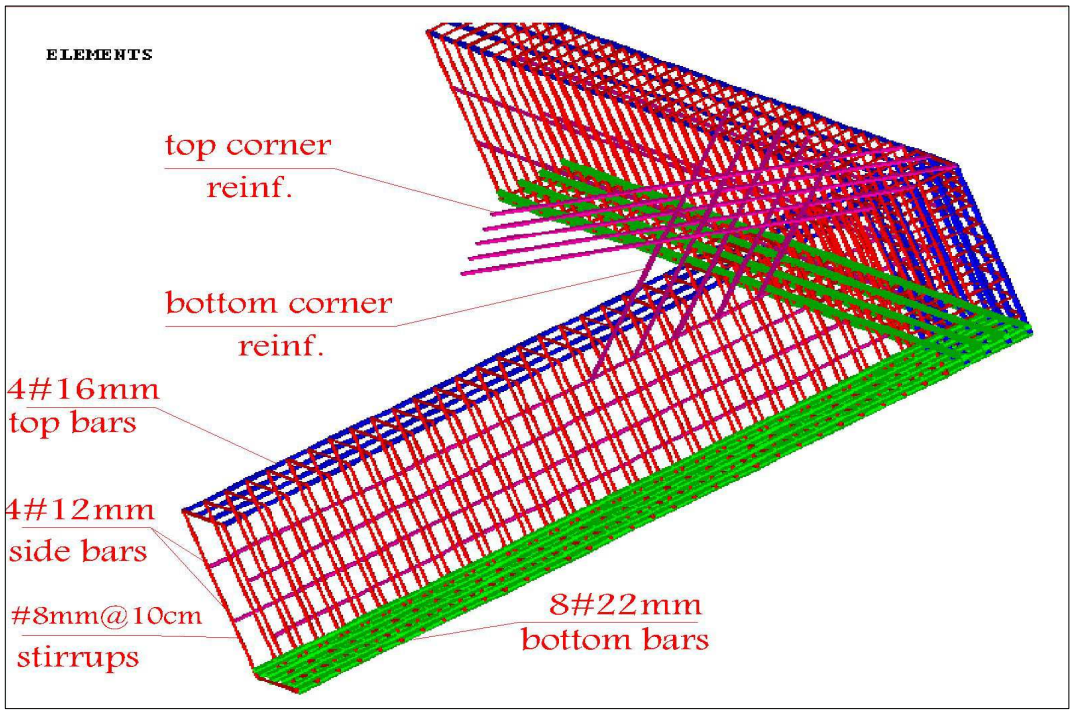

Fig. (9): Beam Reinforcement.

\section{IV- NUMERICAL STUDY}

\section{Parametric study.}

A total of 16 cases for study have been done in this analysis. In order to fulfill the above objective, the effects of the following parameters on the structural behavior of simply supported two-way slab were studied theoretically as shown in table (3).

- $\quad$ All square slabs are $(7 \times 7 \times 0.15 \mathrm{~m})$ and supported on margin beams (30x90) with top reinforcement 4 bars $(16 \mathrm{~mm})$, bottom reinforcement 8bars $(22 \mathrm{~mm})$, Stirrups $8 \mathrm{~mm}$ diameter with $10 \mathrm{~cm}$ spacing and 4 bars $(12 \mathrm{~mm})$ as side bars.

- Group A: The main objective of this group is to illustrate the behavior of slab (shape of failure, stress distribution, the ultimate load carrying capacity \& max displacement)with different percentage and distribution of main reinforcement $(\mu \mathrm{s}=0.38,0.52 \%, 0.67 \%) \mathrm{A} 1, \mathrm{~A} 2, \mathrm{~A} 3$ respectively.

- Group B: The main objective of this group is to illustrate the effect of beam depth on slab behavior.

- Group C: The main objective of this group is to illustrate the effect of beam width on slab behavior.

- Group D: this group studies the effect of using additional top \& bottom corner reinforcement and spacing between bars on shape of failure, stress distribution, the ultimate load capacity \& max displacement. These slabs have 
a bottom and top corner reinforcement (perpendicular to the diagonal) reinforcement with 3 bars $12 \mathrm{~mm}$ diameter ( $\mu=43 \%$ of the main reinforcement) and has spacing between bars $(\mathrm{S}=7,14,21 \mathrm{~cm})$

- Group E: The main objective of studying group E2 is to illustrate the effect of percent of corner reinforcement which has been taken $(72 \%, 100 \%$ of the main steel with 5,7 bars $12 \mathrm{~mm}$ diameter respectively and spacing between bars $S=14 \mathrm{~cm}$ ) on shape of failure, stress distribution, the ultimate load capacity $\&$ max displacement.

- Group F: this group studies the effect of top \& bottom corner reinforcement in case of rectangular slabs $[\mathrm{R}=1.25(7 \mathrm{X} 8.8 \mathrm{X} 0.15), \mathrm{R}=1.5(7 \mathrm{X} 10.6 \mathrm{X} 0.15)]$.

Table (3): The general plan of the parametric study.

\begin{tabular}{|c|c|c|c|c|c|c|c|c|}
\hline \multirow{2}{*}{$\begin{array}{c}\text { GROUP } \\
\text { NO. }\end{array}$} & \multirow{2}{*}{$\begin{array}{c}\text { SLAB } \\
\text { NO. }\end{array}$} & \multirow{2}{*}{$\begin{array}{l}\text { SLAB } \\
\text { DIMENSION } \\
(\mathrm{m})\end{array}$} & \multirow{2}{*}{$\begin{array}{l}\text { MAIN } \\
\text { REINF. }\end{array}$} & \multicolumn{2}{|c|}{ BEAM } & \multirow{2}{*}{$\begin{array}{c}\% \\
\text { OF.C.R } \\
(\mu)\end{array}$} & \multirow{2}{*}{$\begin{array}{c}\text { SPACING } \\
\text { BET.BARS } \\
\text { S(cm) }\end{array}$} & \multirow{2}{*}{$\begin{array}{c}\text { REC. } \\
\text { (R) }\end{array}$} \\
\hline & & & & $\begin{array}{c}\text { WIDTH } \\
(\mathrm{cm})\end{array}$ & $\begin{array}{c}\text { DEPTH } \\
(\mathrm{cm})\end{array}$ & & & \\
\hline \multirow{3}{*}{ A } & A1 & 7X7X0.15 & $\# 12 @ 20 \mathrm{~cm}$ & $30 \mathrm{~cm}$ & $90 \mathrm{~cm}$ & - & - & $\underline{1}$ \\
\hline & A2 & $7 \times 7 \times 0.15$ & $\# 10 @ 10 \mathrm{~cm}$ & $30 \mathrm{~cm}$ & $90 \mathrm{~cm}$ & - & - & 1 \\
\hline & A3 & 7X7X0.15 & $\# 16 @ 20 \mathrm{~cm}$ & $30 \mathrm{~cm}$ & $90 \mathrm{~cm}$ & - & - & $\underline{1}$ \\
\hline \multirow{2}{*}{ B } & B1 & $7 \times 7 \times 0.15$ & $\# 10 @ 10 \mathrm{~cm}$ & $30 \mathrm{~cm}$ & $70 \mathrm{~cm}$ & _ & - & $\underline{1}$ \\
\hline & B2 & 7X7X0.15 & $\# 10 @ 10 \mathrm{~cm}$ & $30 \mathrm{~cm}$ & $110 \mathrm{~cm}$ & - & - & $\underline{1}$ \\
\hline \multirow{2}{*}{$\mathrm{C}$} & $\mathrm{C} 1$ & $7 X 7 X 0.15$ & $\# 10 @ 10 \mathrm{~cm}$ & $40 \mathrm{~cm}$ & $90 \mathrm{~cm}$ & - & - & $\underline{1}$ \\
\hline & $\mathrm{C} 2$ & $7 \times 7 X 0.15$ & \#10@10cm & $20 \mathrm{~cm}$ & $90 \mathrm{~cm}$ & - & - & $\underline{1}$ \\
\hline \multirow{3}{*}{ D } & D1 & $7 X 7 X 0.15$ & $\# 10 @ 10 \mathrm{~cm}$ & $30 \mathrm{~cm}$ & $90 \mathrm{~cm}$ & $\underline{43 \%}$ & $\underline{7 \mathrm{~cm}}$ & $\underline{1}$ \\
\hline & D2 & $7 X 7 X 0.15$ & $\# 10 @ 10 \mathrm{~cm}$ & $30 \mathrm{~cm}$ & $90 \mathrm{~cm}$ & $\underline{43 \%}$ & $\underline{14 \mathrm{~cm}}$ & $\underline{1}$ \\
\hline & D3 & $7 \times 7 \times 0.15$ & \#10@10cm & $30 \mathrm{~cm}$ & $90 \mathrm{~cm}$ & $\underline{43 \%}$ & $\underline{21 \mathrm{~cm}}$ & $\underline{1}$ \\
\hline \multirow{2}{*}{ E } & E1 & $7 \times 7 X 0.15$ & $\# 10 @ 10 \mathrm{~cm}$ & $30 \mathrm{~cm}$ & $90 \mathrm{~cm}$ & $\underline{72 \%}$ & $\underline{14 \mathrm{~cm}}$ & $\underline{1}$ \\
\hline & E2 & $7 X 7 X 0.15$ & $\# 10 @ 10 \mathrm{~cm}$ & $30 \mathrm{~cm}$ & $90 \mathrm{~cm}$ & $\underline{100 \%}$ & $\underline{14 \mathrm{~cm}}$ & $\underline{1}$ \\
\hline \multirow{4}{*}{$\mathrm{F}$} & $\mathrm{F} 1$ & 7X8.8X0.15 & $\# 10 @ 10 \mathrm{~cm}$ & $30 \mathrm{~cm}$ & $110 \mathrm{~cm}$ & - & - & $\underline{1.25}$ \\
\hline & $\mathrm{F} 2$ & 7X8.8X0.16 & $\# 10 @ 10 \mathrm{~cm}$ & $30 \mathrm{~cm}$ & $110 \mathrm{~cm}$ & - & - & $\underline{1.5}$ \\
\hline & F3 & $7 \times 10.6 \times 0.14$ & $\# 10 @ 10 \mathrm{~cm}$ & $30 \mathrm{~cm}$ & $110 \mathrm{~cm}$ & $100 \%$ & $14 \mathrm{~cm}$ & $\underline{1.25}$ \\
\hline & F4 & $7 \times 10.6 \times 0.15$ & $\# 10 @ 10 \mathrm{~cm}$ & $30 \mathrm{~cm}$ & $110 \mathrm{~cm}$ & $100 \%$ & $14 \mathrm{~cm}$ & 1.5 \\
\hline
\end{tabular}




\section{Numerical results}

\section{Slab-A2 (reference slab):}

- Slab start to crack at load $\left(1.083 \mathrm{t} / \mathrm{m}^{2}\right)$ at the bottom(parallel to the diagonal) and top (perpendicular to the diagonal)corner fiber, then it propagate gradually towards slab center with increase loading up to failure load (3.103 $\mathrm{t} / \mathrm{m}^{2}$ ) Figs. (10) and (11).

- Steel reinforcement reached the yield stress at load $\left(2.373 \mathrm{t} / \mathrm{m}^{2}\right)$ at the slab center due to tension stresses Fig. (12).

- From the above it can be deduce that slab failure caused by:

After the Steel reinforcement reached the yield stress the slab corner subjected to strong stresses (sxy shear stress) leading to concrete crushing at the bottom corner. And consequently the collapse of slab occurred due to the increase of these stresses.

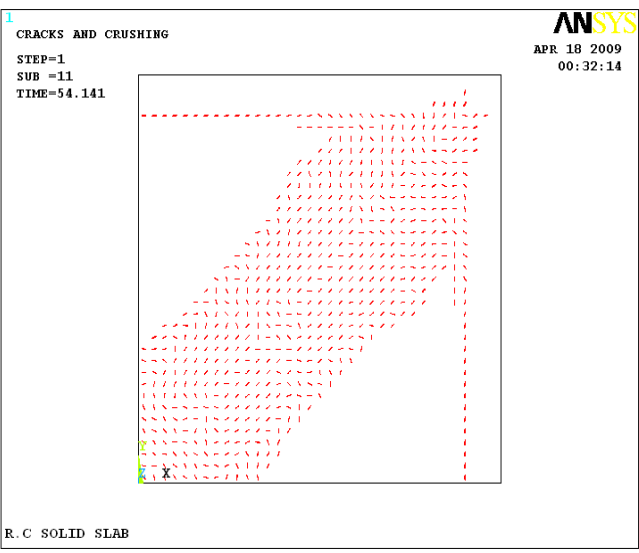

(a)

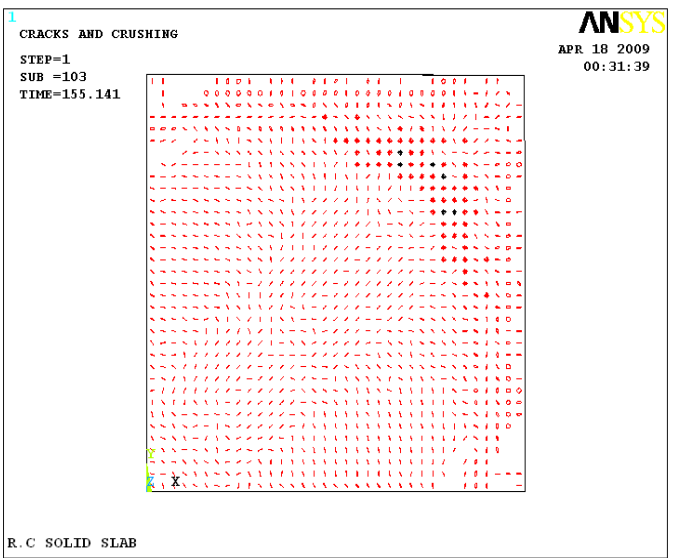

(b)

Fig. (10): Cracking shape for slab (A2); ( a) at load=1.083 t/m². (b) At failure load $=3.10282 \mathrm{t} / \mathrm{m}^{2}$ for bottom surface

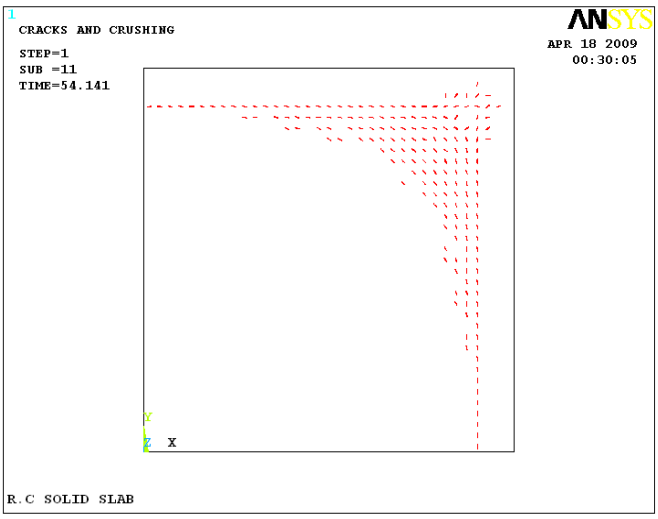

(a)

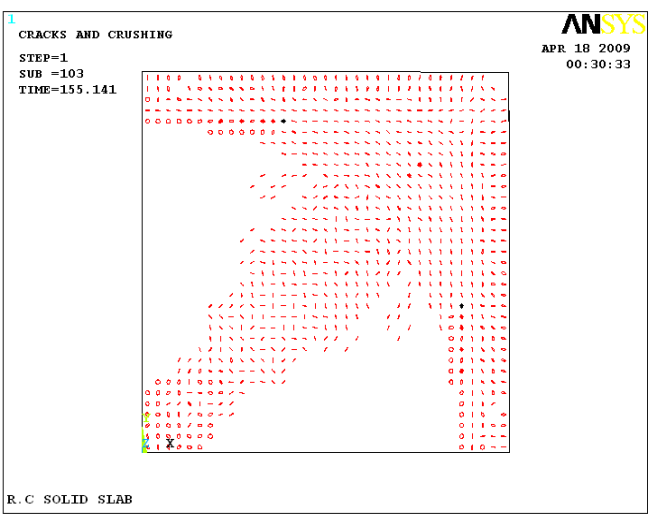

(b)

Fig. (11): Cracking shape for slab (A2);( a) at load=1.083 t/m². (b) At failure load $=3.10282 \mathrm{t} / \mathrm{m}^{2}$ for top surface. 


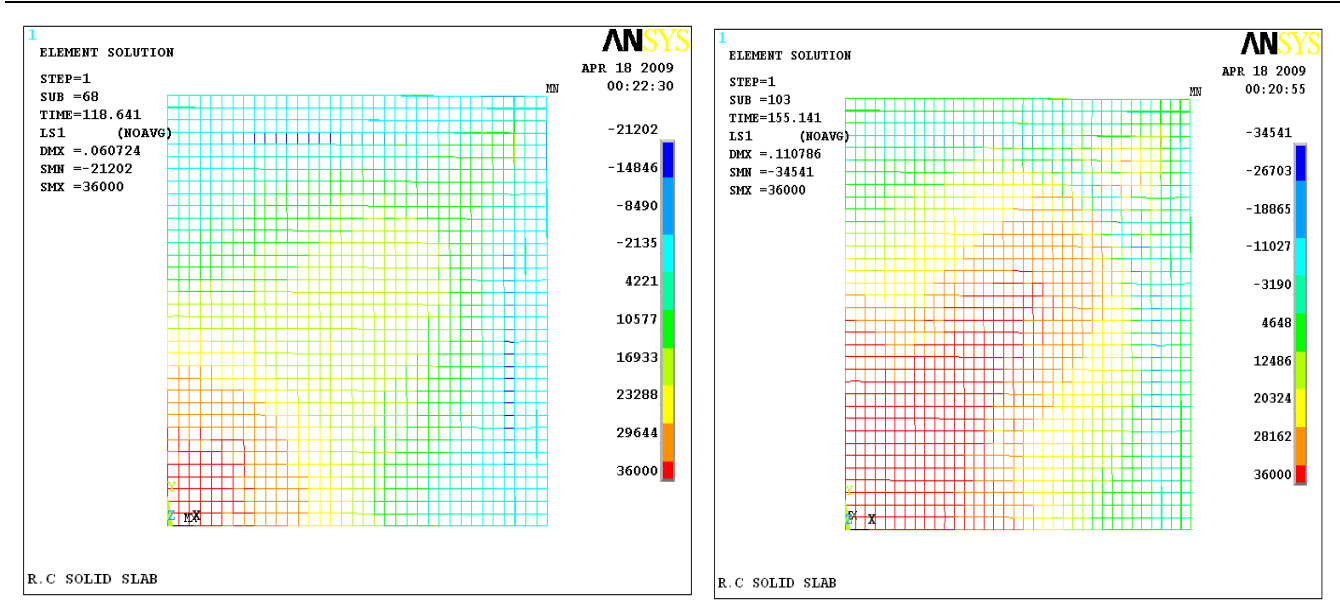

Fig. (12): Yield stress for steel element ;( a) First yield stress for steel element. (b) Yield stress at failure load for slab (A2).
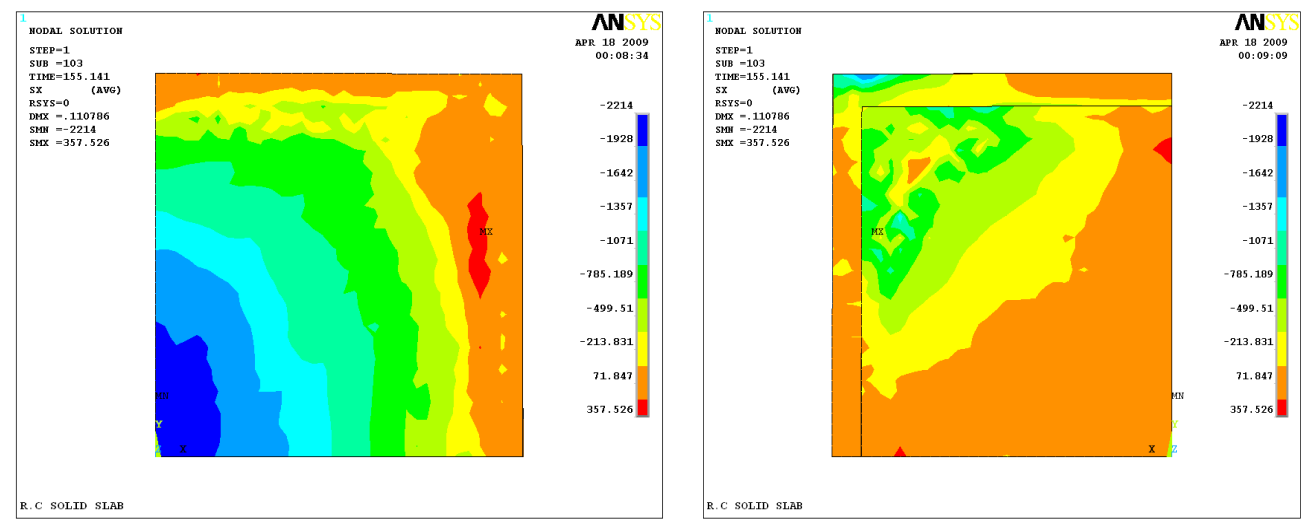

Fig. (13): Component of Stress distribution shape in X direction ;(a) Sx at top surface;(b) Sx at bottom surface)

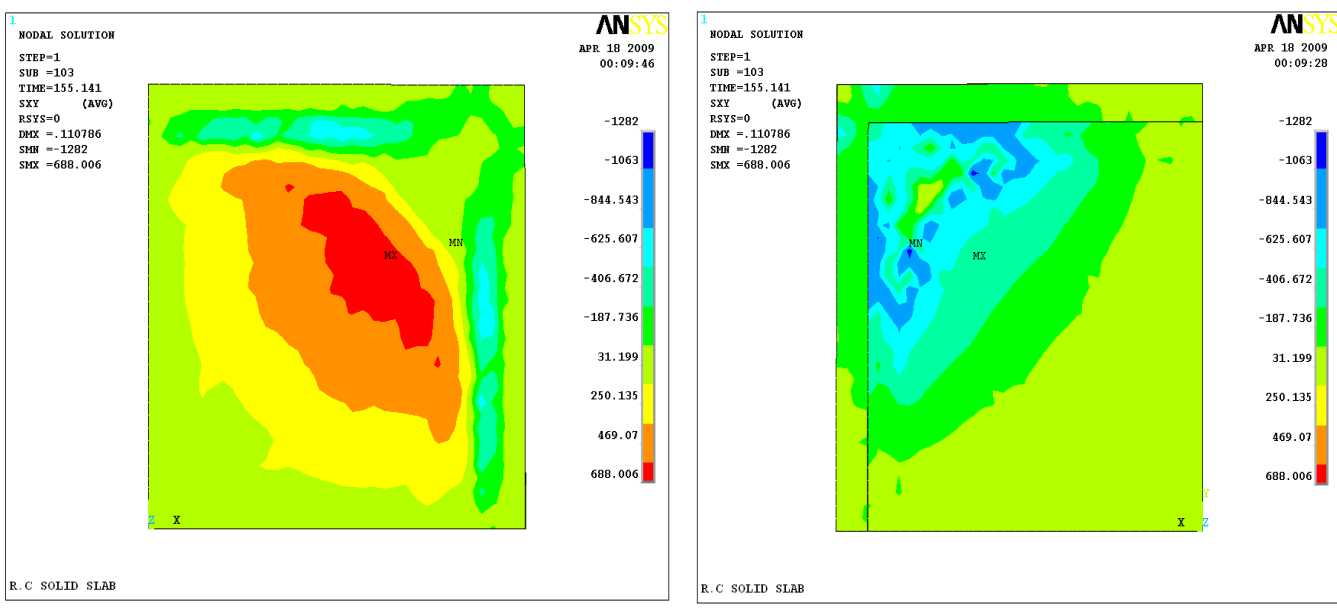

Fig. (14): Shear Stress distribution shape for slab (A2) in XY direction ;(a) Sxy at top surface;(b) Sxy at bottom surface. 


\section{Group A:}

- When load is applied to the slab the first cracks to form is a roughly circular tangential crack around the parameter of loaded area due to negative bending moment in the radial direction.

- Increasing percent of main steel reinforcement from $\mu=0.38 \%$ (A1) to $\mu=0.67 \%$ (A3) improves the ultimate load carrying capacity from $\left(2.363 \mathrm{t} / \mathrm{m}^{2}\right.$ to $\left.3.338 \mathrm{t} / \mathrm{m}^{2}\right)$ by about $41 \%$, and decrease the max displacement from $(8.66 \mathrm{~cm}$ at failure load $=2.363 \mathrm{t} / \mathrm{m}^{2}$ for slab A1) to $(5.57 \mathrm{~cm}$ at the same load $=2.363$ $\mathrm{t} / \mathrm{m}^{2}$ for slab A3) by about $55 \%$.

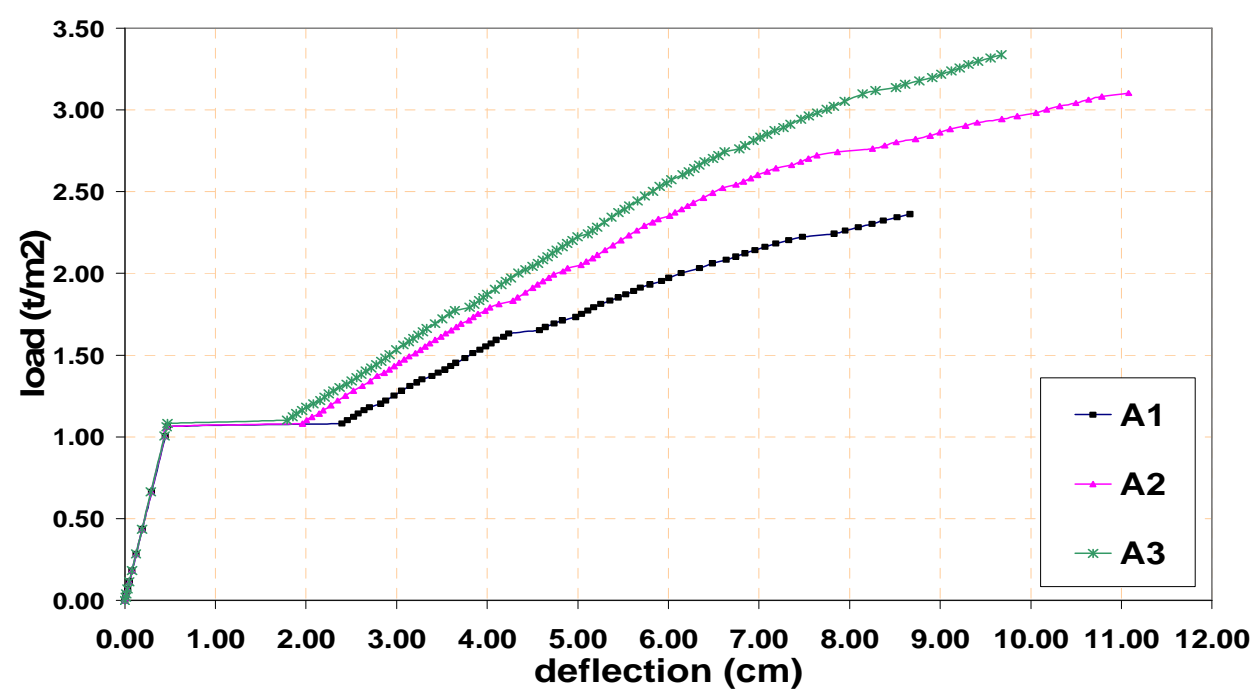

Fig. (15): Load deflection curve for group (A).

\section{(GROUP B):}

- From studying this group it can be deduced that increasing beam depth from $(70 \mathrm{~cm}$ to $90 \mathrm{~cm}) \mathrm{B} 1$, A2 respectively have a small effect on improving slab load carrying capacity which was $(6.04 \%)$.Increasing beam depth from $(90 \mathrm{~cm}$ to $110 \mathrm{~cm})$ A2, B2 respectively have also a small effect on improving slab load carrying capacity which was $(1.69 \%)$, at the same time it decrease central deflection by $(1.0 \%)$.

\section{(GROUP C):}

Results of this group can be summarized as follows:

- Increasing beam width from $B=20$ (C2) to $B=30$ (A2) improves the ultimate load carrying capacity from $\left(2.469 \mathrm{t} / \mathrm{m}^{2}\right.$ to $\left.3.103 \mathrm{t} / \mathrm{m}^{2}\right)$ by about $20 \%$ and decrease max displacement from $(8.143 \mathrm{~cm}$ to $6.408 \mathrm{~cm}$ at load 2.469$)$ by about $21 \%$.

- Increasing beam width from $B=30$ (A2) to $B=40$ (C1) improves the ultimate load carrying capacity from $\left(3.103 \mathrm{t} / \mathrm{m}^{2}\right.$ to $\left.3.390 \mathrm{t} / \mathrm{m}^{2}\right)$ by about $9 \%$ and decrease max displacement from $(11.078 \mathrm{~cm}$ to $7.089 \mathrm{~cm}$ at load 3.103$)$ by about $36 \%$ 


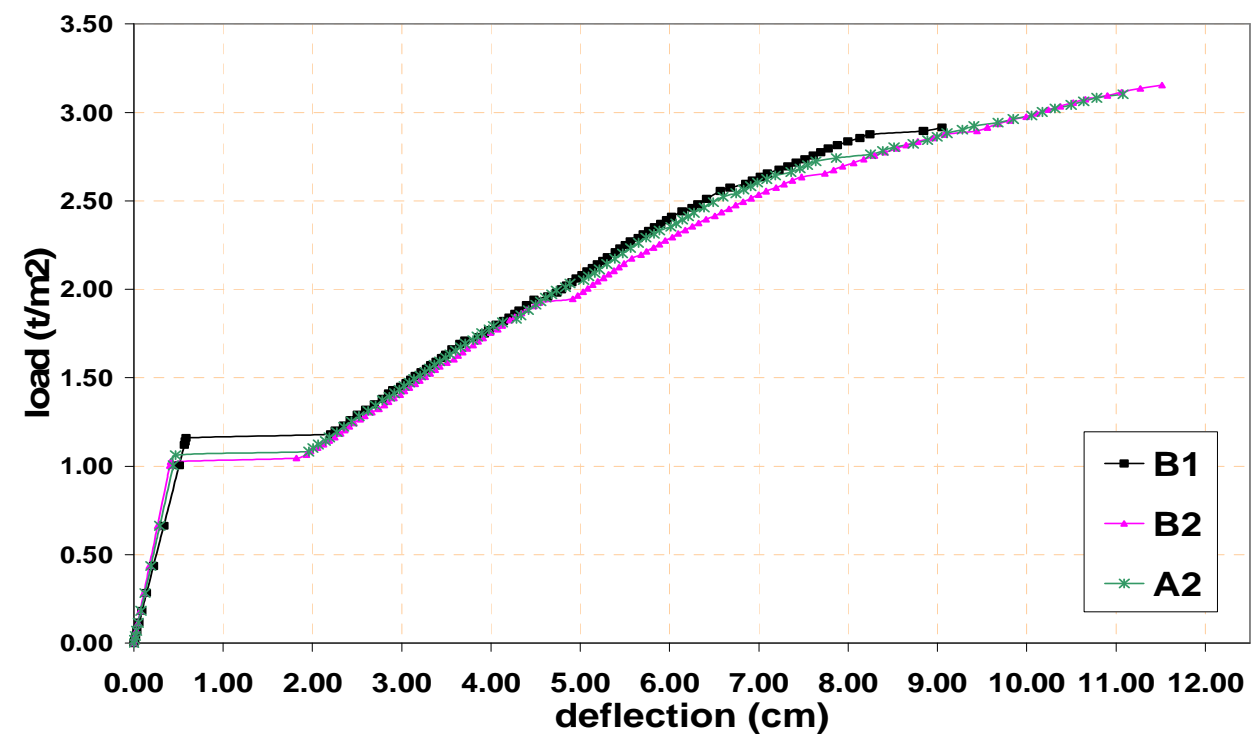

Fig. (16): Load deflection curve for group (B).

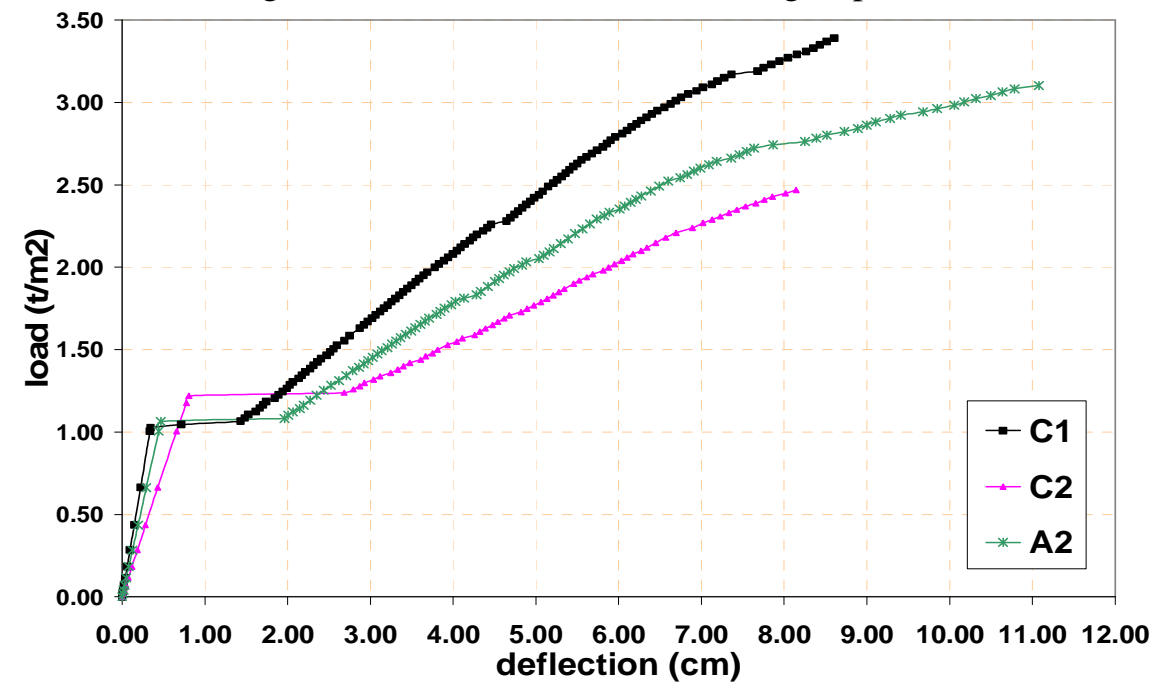

Fig. (17): Load deflection curve for group (C).

\section{(GROUP D):}

- Slabs D1, D2, D3 start to crack at the same loading value $\left(1.103, \mathrm{t} / \mathrm{m}^{2}\right)$ in direction of parallel to the diagonal (at the bottom) and perpendicular to the diagonal (at the top) corner fiber, then it propagate gradually towards slab center with increase loading up to failure load.

- By comparing Pcr for A2 and group D it can be seen that; Corner reinforcement has a considerable effect on Pcr for such slabs, spacing between corner reinforcement do not effect on Pcr.

- Steel reinforcement reached the yield stress at load $\left(2.323,2.483,2.303 \mathrm{t} / \mathrm{m}^{2}\right)$ for D1, D2, D3 respectively at the slab center and the additional corner reinforcement due to tension stresses Fig. (19). 
○ From the above it can be deduce that After the Steel reinforcement reached the yield stress the slab corner subjected to strong stresses (sxy shear stress) leading to concrete cracking and crushing at the slab corner.

- Testing slab D2 $(\mathrm{S}=14 \mathrm{~cm})$ with changing the spacing between corner reinforcement to illustrate the effect of using different spacing between corner reinforcement $S=7 \mathrm{~cm}$ (D1), $21 \mathrm{~cm}$ (D3) it can be seen that the best spacing for corner reinforcement is $14 \mathrm{~cm}$ see Table (4), Fig. (20).

- Using this top and bottom corner reinforcement with a percent $43 \%$ from the main reinforcement improve the ultimate load capacity by (2\% to $5 \%)$ and decrease the max. Displacement by (13\% to16\%) depends on spacing between corner reinforcement.

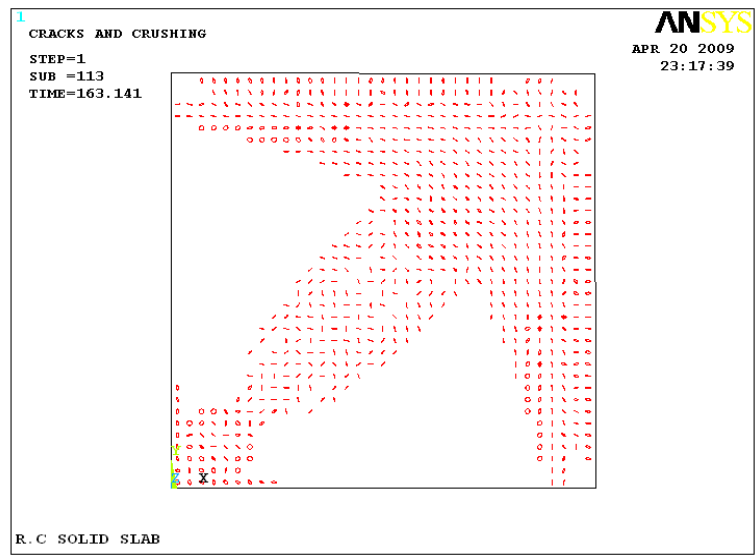

Fig. (18): Cracking shape for slab (D2) at failure load=3.263 t/m $\mathrm{m}^{2}$ for top surface.

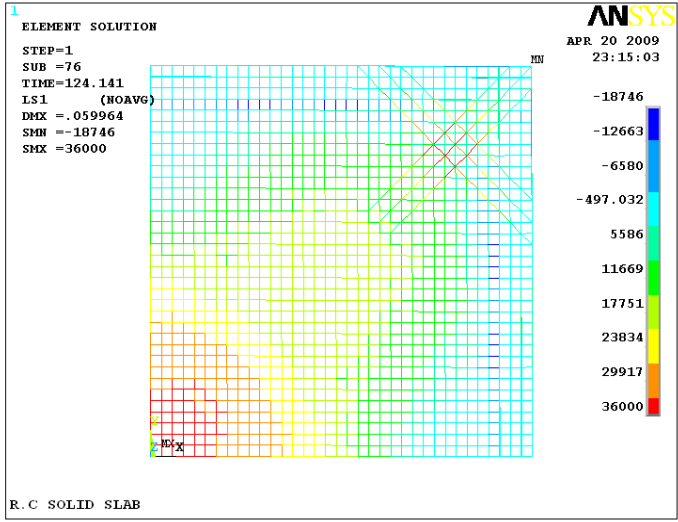

(a)

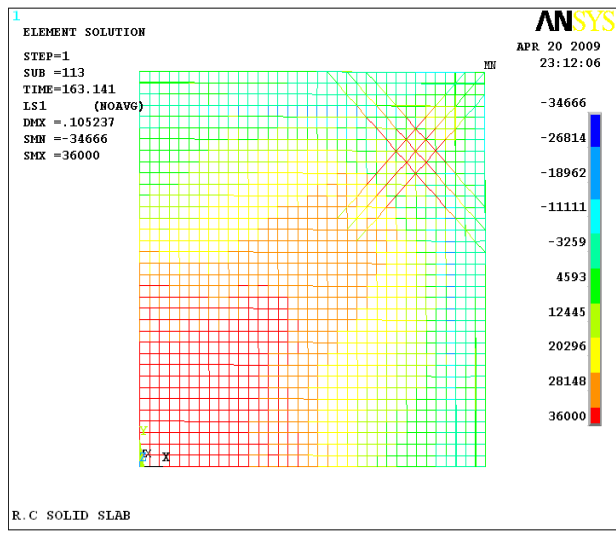

(b)

Fig. (19): yield stress for steel element ;( a) First yield stress for steel element. (b)

Yield stress at failure load for slab (D2). 


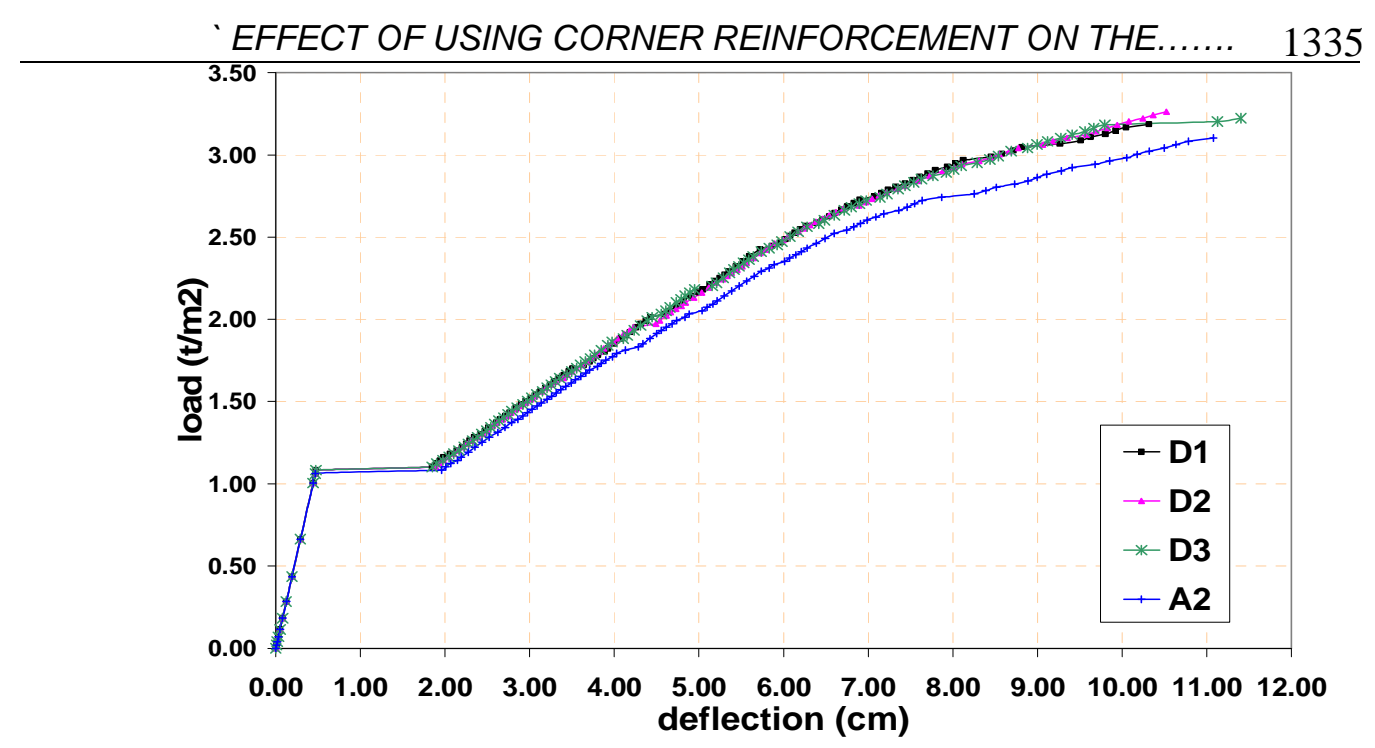

Fig. (20): Load deflection curve for slabs D1, D2, D3, and A2.

\section{Group (E):}

- Slabs E1, E2 start to crack at the same loading value $\left(1.089 \mathrm{t} / \mathrm{m}^{2}\right)$ in direction of parallel to the diagonal (at the bottom) and perpendicular to the diagonal (at the top)corner fiber, then it propagate gradually towards slab center with increase loading up to failure load.

- Steel reinforcement reached the yield stress at load $\left(2.480,2.171 \mathrm{t} / \mathrm{m}^{2}\right)$ for slabs E1, E2 respectively at the slab center and the additional corner reinforcement due to tension stresses Fig. (22).

- When the load is further increased, stress and strain rise correspondingly and are no longer proportional. Eventually the carrying capacity of the slab is reached failure happens because of the steel will reach its yield point. After that stress the reinforcement yields stretches and the tension cracks in the concrete widen visibly and propagate upwards, with simultaneous significant deflection of the slab. When this happens, the strains in the remaining compression zone of the concrete increase to such a degree that crushing of the concrete.

- All the cracks and stresses shape for slabs E1, E2 taking the same shape as slab A2.

- Using this top and bottom corner reinforcement corner reinforcement with a percent $72 \%$ (E1), 100\% (E2) from the main reinforcement improve the ultimate load capacity by (7\%-10\%) respectively and decrease the max. Displacement by (24\% to 30\%) respectively at spacing $14 \mathrm{~cm}$ Fig (23).

- The foregoing it can be concluded that slab corner subjected to torsional moment produce a tensile stresses at the underside of the slab (perpendicular to diagonal) at the same time it subjected to shear stresses produce tensile stresses at the upper side of the slab (parallel to diagonal), for this reason, steel reinforcing bars are placed on the tension side as close the extreme tension fiber and resist the tension stresses. 


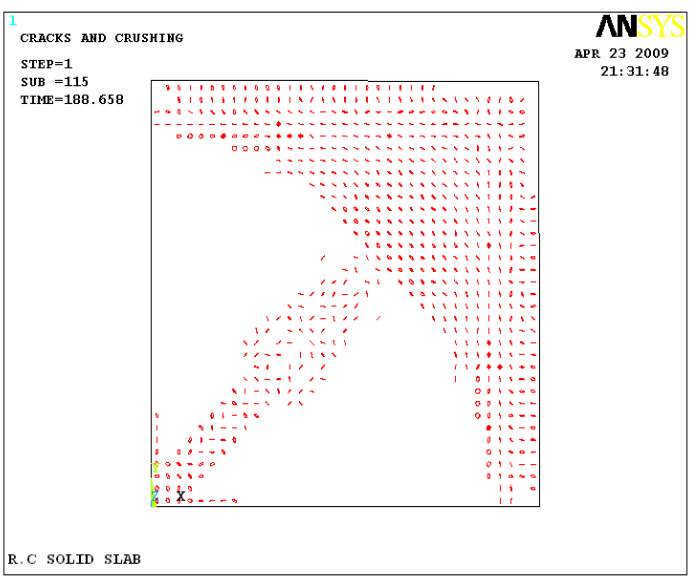

Fig. (21): Cracking shape for slab (E2) at failure load for slab (E2) .

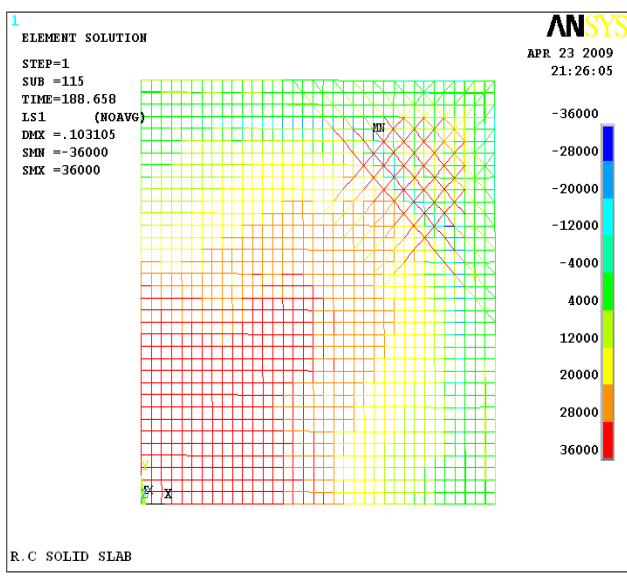

Fig. (22): Yield stress for steel element at failure load for slab (E2) .

- By Increasing the percent of steel reinforcement from $\mu \mathrm{s}=0.52 \%$ (A2) to $\mu \mathrm{s}=0.67 \%(\mathrm{~A} 3)$ the ultimate load carrying capacity improved from $\left(3.103 \mathrm{t} / \mathrm{m}^{2}\right.$ to $3.338 \mathrm{t} / \mathrm{m}^{2}$ ) by about $7 \%$. From another view it can be seen that using corner reinforcement with percent $100 \%$ and spacing $14 \mathrm{~cm}$ (E2) improves the ultimate load carrying capacity from $\left(3.103 \mathrm{t} / \mathrm{m}^{2}\right.$ to $\left.3.430 \mathrm{t} / \mathrm{m}^{2}\right)$ by about $10 \%$ Fig (24). which means that using corner reinforcement has a better effect than increasing the percent of main reinforcement see from the economic point of view.

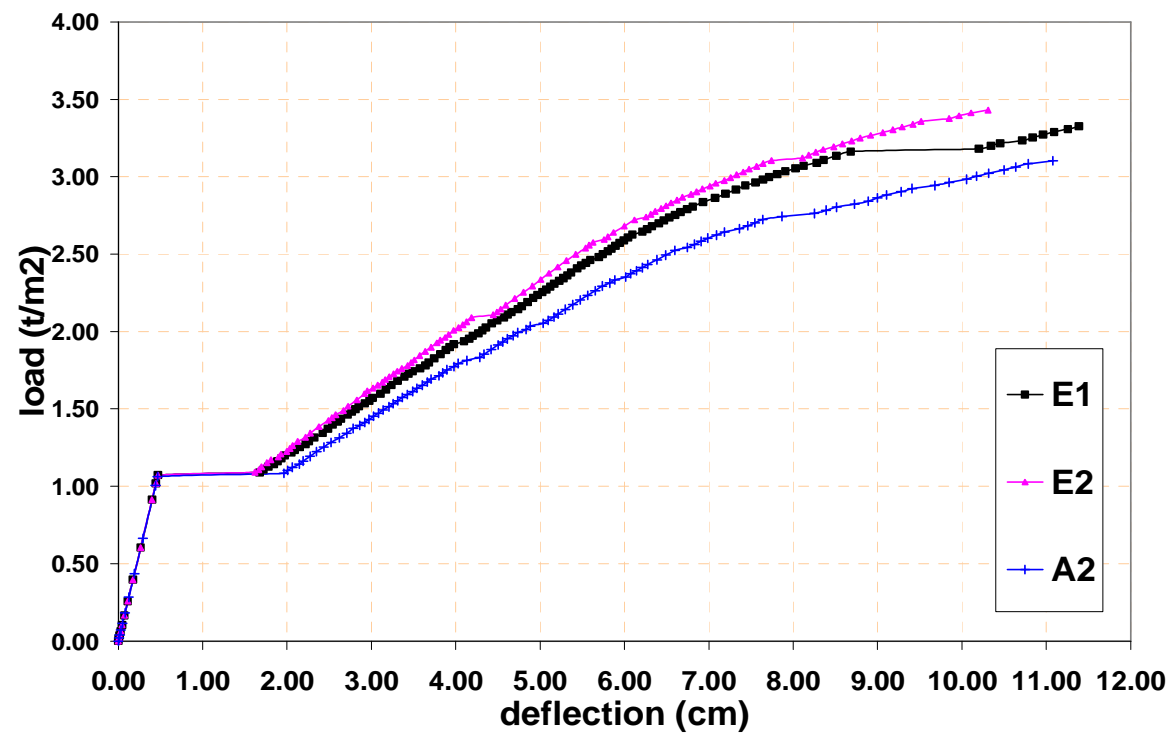

Fig. (23): Load deflection curve for slabs E1, E2, and A2. 


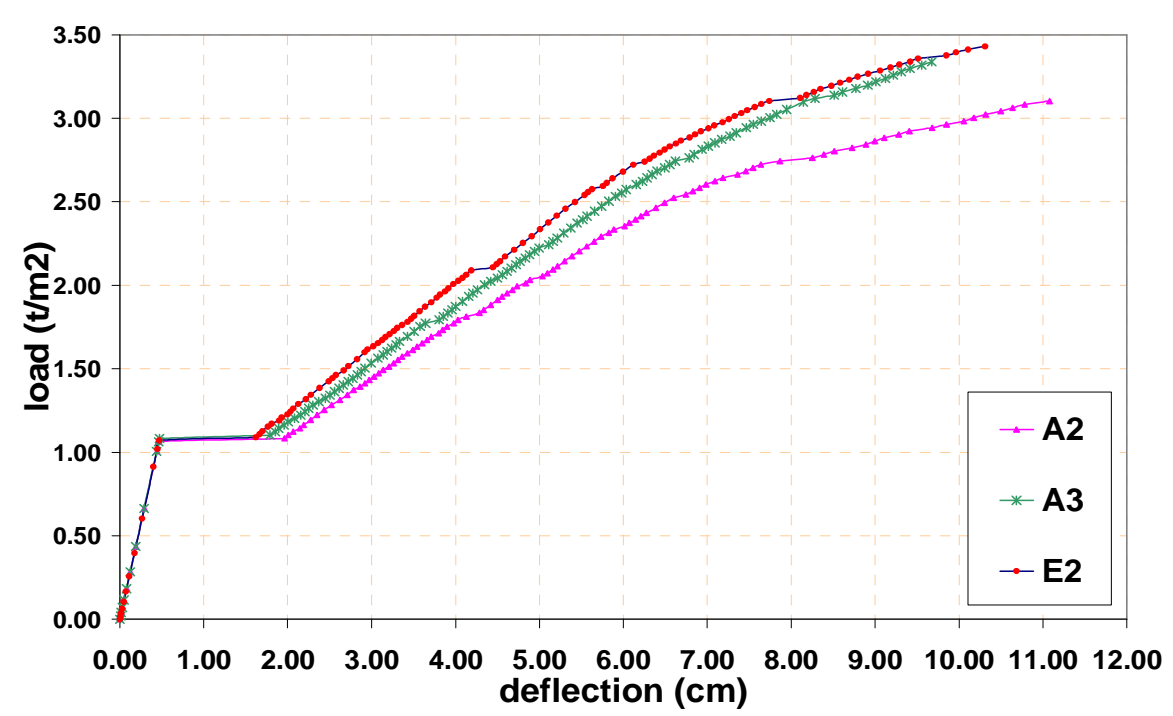

Fig. (24): Load deflection curve for slabs A2, A3, and E2.

Table (4) the results of parametric study.

\begin{tabular}{|c|c|c|c|c|c|c|c|c|}
\hline $\begin{array}{c}\text { GROUP } \\
\text { NO. }\end{array}$ & $\begin{array}{c}\text { SLAB } \\
\text { NO. }\end{array}$ & $\begin{array}{c}\mathrm{PU} \\
\mathrm{t} / \mathrm{m} 2\end{array}$ & $\begin{array}{c}\text { increase } \\
\mathrm{Pu}\end{array}$ & $\begin{array}{c}\delta \mathrm{max} \\
\mathrm{cm}\end{array}$ & $\delta 0$ & $\begin{array}{c}\% \\
\text { decrease } \\
\delta 0\end{array}$ & $\begin{array}{c}\text { Pcr } \\
\mathrm{t} / \mathrm{m} 2\end{array}$ & $\begin{array}{c}\text { Py } \\
\mathrm{t} / \mathrm{m} 2\end{array}$ \\
\hline \multirow{3}{*}{$\mathrm{A}$} & $\mathrm{A} 1$ & 2.363 & $-23.85 \%$ & 8.664 & 0.000 & $0.0 \%$ & 1.083 & 1.793 \\
\cline { 2 - 10 } & $\mathrm{A} 2$ & 3.103 & $0.00 \%$ & 11.08 & 11.078 & $0.0 \%$ & 1.083 & 2.373 \\
\cline { 2 - 10 } & $\mathrm{A} 3$ & 3.338 & $7.57 \%$ & 9.675 & 8.180 & $-26.2 \%$ & 1.103 & 2.573 \\
\hline \multirow{2}{*}{$\mathrm{B}$} & $\mathrm{B} 1$ & 2.915 & $-6.04 \%$ & 9.050 & 0.000 & $0.0 \%$ & 1.180 & 2.440 \\
\cline { 2 - 10 } & $\mathrm{B} 2$ & 3.155 & $1.69 \%$ & 11.515 & 10.967 & $-1.0 \%$ & 1.045 & 2.235 \\
\hline \multirow{2}{*}{$\mathrm{C}$} & $\mathrm{C} 1$ & 3.390 & $9.26 \%$ & 8.606 & 7.088 & $-36.0 \%$ & 1.045 & 2.650 \\
\cline { 2 - 9 } & $\mathrm{C} 2$ & 2.469 & $-20.43 \%$ & 8.143 & 0.000 & $0.0 \%$ & 1.005 & 2.119 \\
\hline \multirow{3}{*}{$\mathrm{D}$} & $\mathrm{D} 1$ & 3.188 & $2.74 \%$ & 10.32 & 9.627 & $-13.1 \%$ & 1.103 & 2.323 \\
\cline { 2 - 9 } & $\mathrm{D} 2$ & 3.263 & $5.16 \%$ & 10.52 & 9.350 & $-15.6 \%$ & 1.103 & 2.483 \\
\cline { 2 - 9 } & $\mathrm{D} 3$ & 3.223 & $3.87 \%$ & 11.4 & 9.274 & $-16.3 \%$ & 1.103 & 2.303 \\
\hline \multirow{2}{*}{$\mathrm{E}$} & $\mathrm{E} 1$ & 3.326 & $7.18 \%$ & 11.39 & 8.360 & $-24.5 \%$ & 1.089 & 2.480 \\
\cline { 2 - 9 } & $\mathrm{E} 2$ & 3.430 & $10.55 \%$ & 10.31 & 7.740 & $-30.1 \%$ & 1.089 & 2.171 \\
\hline
\end{tabular}

\section{Group (F):}

Corner reinforcement effect for rectangular slab can be deduced as follow:

- Using corner reinforcement with percentage $100 \%$ of the main reinforcement and spacing $14 \mathrm{~cm}$ Increase significantly the slab load carrying capacity from ( 2.277 to $2.569 \mathrm{t} / \mathrm{m}^{2}$ ) by about $12.82 \%$ in case of rectangularity $=1.25(\mathrm{~F} 3)$. At the same time it decrease considerably the slab central deflection from $[12.081 \mathrm{~cm}$, (F1) to $9.520 \mathrm{~cm}(\mathrm{~F} 3)]$ at the same load value $2.277 \mathrm{t} / \mathrm{m}^{2}$ by about $21.2 \%$. 
- When slab rectangularity $=1.5$ the corner reinforcement has a considerable effect on load carrying capacity which increases from $\left(1.472\right.$ to $\left.1.888 \mathrm{t} / \mathrm{m}^{2}\right)$ by about $28.26 \%$. And decrease central deflection from $[7.905 \mathrm{~cm},(\mathrm{~F} 2)$ to $6.831 \mathrm{~cm}(\mathrm{~F} 4)]$ by about $13.6 \%$.

- Using corner reinforcement with percentage $100 \%$ of the main reinforcement and spacing $14 \mathrm{~cm}$ Increase the first yield load from $\left(1.517\right.$ to $\left.1.730 \mathrm{t} / \mathrm{m}^{2}\right)$ by about $14.04 \%$ for slab rectangularity $=1.25$.at the same time it increase the first yield load from $\left(1.272\right.$ to $\left.1.325 \mathrm{t} / \mathrm{m}^{2}\right)$ by about $4.17 \%$ for slab rectangularity $=$ 1.50 .

Table (5) the results of parametric study.

\begin{tabular}{|c|c|c|c|c|c|c|c|c|c|}
\hline \multirow{2}{*}{$\begin{array}{c}\text { GROUP } \\
\text { NO. }\end{array}$} & $\begin{array}{c}\text { SLAB } \\
\text { NO. }\end{array}$ & $\begin{array}{c}\text { PU } \\
\mathrm{t} / \mathrm{m} 2\end{array}$ & $\begin{array}{c}\% \\
\text { increase } \\
\mathrm{Pu}\end{array}$ & $\begin{array}{c}\delta \mathrm{max} \\
\mathrm{cm}\end{array}$ & $\delta 0$ & $\begin{array}{c}\% \\
\text { decrease } \\
\delta 0\end{array}$ & $\begin{array}{c}\text { Pcr } \\
\mathrm{t} / \mathrm{m} 2\end{array}$ & $\begin{array}{c}\text { Py } \\
\mathrm{t} / \mathrm{m} 2\end{array}$ & $\begin{array}{c}\% \\
\text { increase } \\
\text { Py }\end{array}$ \\
\hline \multirow{4}{*}{$\mathrm{F}$} & $\mathrm{F} 1$ & 2.277 & $0.00 \%$ & 12.081 & 12.081 & $0.0 \%$ & 0.857 & 1.517 & $0.0 \%$ \\
\cline { 2 - 11 } & $\mathrm{F} 2$ & 1.472 & $0.00 \%$ & 7.905 & 7.905 & $0.0 \%$ & 0.744 & 1.272 & $0.0 \%$ \\
\cline { 2 - 11 } & $\mathrm{F} 3$ & 2.569 & $12.82 \%$ & 12.777 & 9.520 & $21.2 \%$ & 0.854 & 1.730 & $14.04 \%$ \\
\cline { 2 - 10 } & $\mathrm{F} 4$ & 1.888 & $28.26 \%$ & 11.553 & 6.831 & $13.6 \%$ & 0.761 & 1.325 & $4.17 \%$ \\
\hline
\end{tabular}

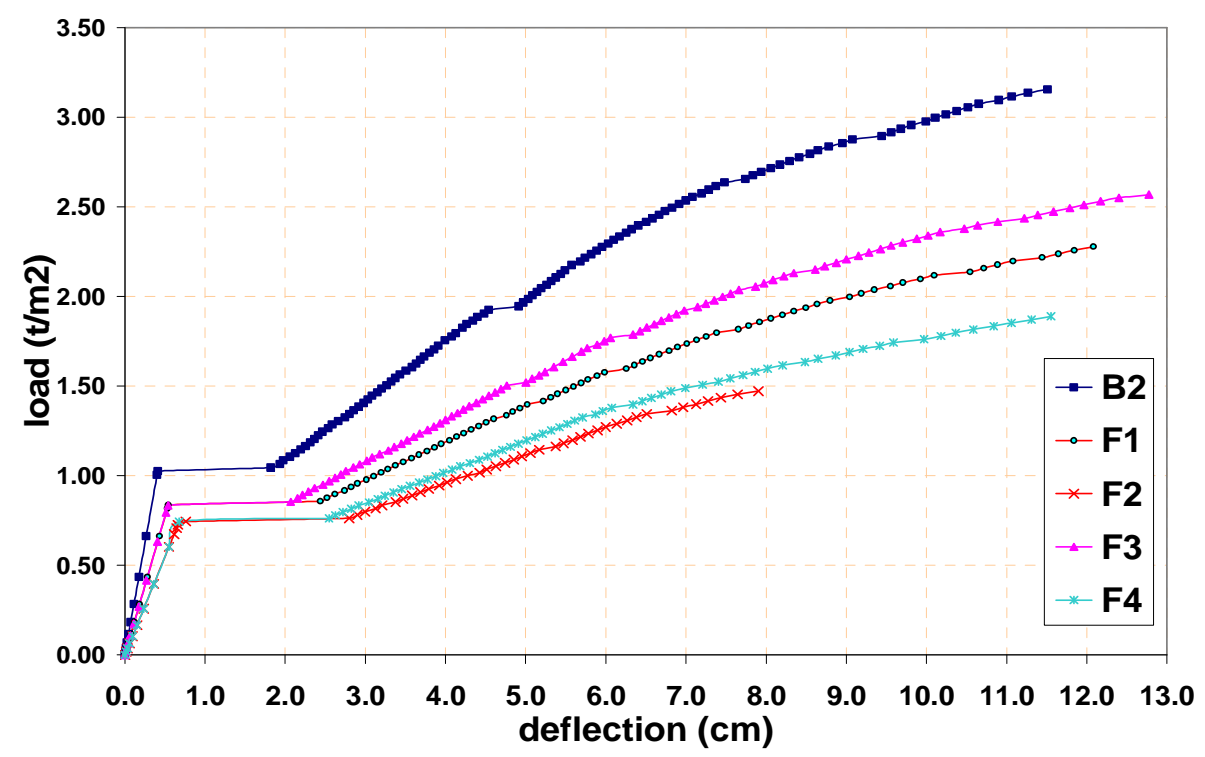

Fig. (4-23): Load deflection curve for group (F).

\section{V- CONCLUSIONS}

Several important conclusions have been drawn out of the presented study:

- The exsistance of corner reinforcement in R.C slabs, improves considerably the structural behaviour of such slabs leading to higher ultimate load carrying capacity and lower values for deflection.The increase in load carrying capacity 
ranges between (5\% to $28 \%$ ) and the decrease in max. deflection ranges between $(13 \%$ to $30 \%)$ depending on slab rectangularity, percentage and spacing of additional corner reinforcement which was taken (43\% to $100 \%)$ of the required main steel per meter.

- For both top and bottom corner reinforcement the optimum gain can be achieved at a percent value $100 \%$ of the main reinforcement of the slab, with spacing between the diagonal corner reinforcement $14 \mathrm{~cm}$.

- Increasing the percentage of main reinforcement from $\mu \mathrm{s}=0.52 \%$ to $\mu \mathrm{s}=0.67 \%$ improves the ultimate load carrying capacity by about $7 \%$. meanwhile it can be seen that using corner reinforcement with percent $100 \%$ and spacing $14 \mathrm{~cm}$ improves the ultimate load carrying capacity by about $10 \%$.which means that the economic point of view, using corner reinforcement is beneficial than increasing the percent of main reinforcement.

- Increasing the margin beam stiffness improves significantly the ultimate load carrying capacity by about $20 \%$, and decrease maximum central defflection by about $36 \%$.

\section{VI- REFRENCE}

1. The' British Standard Code OF Practice (BSI)

2. the American concrete institute (ACI-318-02)

3. Dipl.-Ing.J.Hahn(Structural Analysis of Beams and Slabs).

4. Shaker El-Behairy(Reinforced Concrete Design Handbook) ,Ain Shams University, Sixth Edition,2001.

5. S. Zhou, D.C. Rizos *, M.F. Petrou (Effects of Superstructure Flexibility on Strength of Reinforced Concrete Bridge Decks) University of South Carolina, 300 Main Street, Columbia, SC 29208, USA. August 2003.

6. R.Santhakumar and E.Chandrasekaran (Analysis of Retrofitted Reinforced Concrete Shear Beams Using Carbon Fiber Composites.)Electronic Journal of structural Engineering, Anna University, India.2004.

7. Sahah, S.P., Swartz, S.E. and Ouyang, C. (Fracture Mechanics of Concrete)John Wily \& Sons,Inc. New York, 1995.

8. Bangash M.Y.H (Concrete and Concrete Structure: Numerical Modeling and Applications (Elsevier Science Publishers Ltd.,London, England 1989.

9. Desayi, P and Krishnan, S (Equation for the Stress-Strain Curve of Concrete (Journal of the American concrete institute, 61, pp.345-350, March 1964.

10.Gere, J .M and Timoshenko, S.P.(Mechanics of Materials)PWS publishing company, Boston, Massachusetts,1997. 


\section{تأثير تسليح الاركان على السلوك الإنشائى للبلاطات الخرسانية المسلحة المصمته}

جرت العادة الى إستخدام البلاطات المصمته كنظام إنشائى غير مكلف إقتصادياً وذلك لمعظم الأسقف الخرسانيه الإعتياديه. غير أن هذا النظام الإنشائى يفضل إستخدامه فى البحور الصغيره نظراً لها تتعرض له من صعوبات

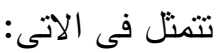
زيادة إزاحات البلاطات فى البحور الكبيره نسبياً. عدم قدرة البلاطه على إستيعاب أحمال كبيره بزيادة البحر .

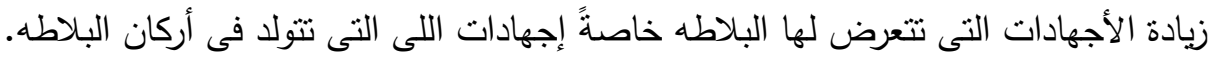

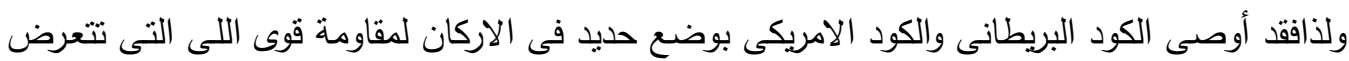
ل لها أركان البلاطه فقد أوصى الكود البربطانى بالاتى: البلاطه

إضسافة شبكتين سفليه وعلويه فى الاتجاهين فى أركان البلاطات الدصمته يتث توزيعها على لئى

$$
\text { مسافه تقدر بـ (خمس البحر القصير). }
$$

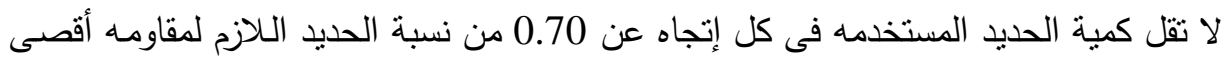

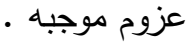

$$
\begin{aligned}
& \text { أما الكود الامريكى فقد أوصى بالاتى: }
\end{aligned}
$$

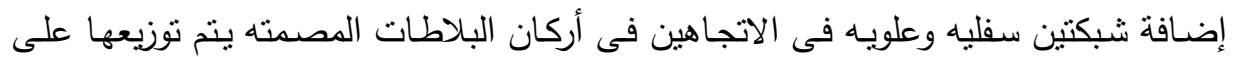

$$
\text { مسافه تقدر بـ (خمس البحر الطويل). }
$$

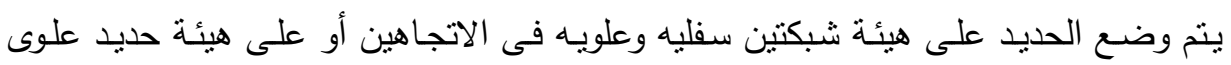
عمودى على قطر البلاطه وسفلى موازى له. لا تقل كمية الحديد المستخدمه فى كل إتجاه عن الحديد اللازم لمقاومه أقصى عزومى موريه موجبه تتعرض لها البلاطه.

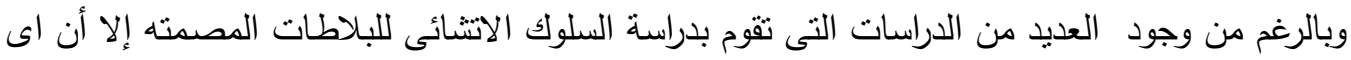

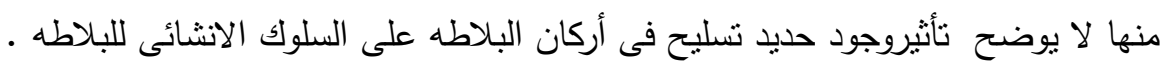

\section{ومن ثم كان الغرض الاساسى من هذا البحث هو :} دراسة تأثير حديد الاركان للبلاطه على تقليل الاجهادات والإزاحات وزيادة الحمل الأقصى للبلاطات

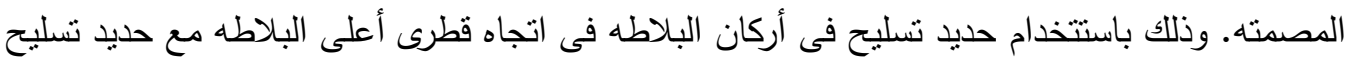
سفلى عمودى على المحور القطرى وذللك فى خمس البحرللبلاطه وبنفس كمية الحديد العلوى. وذللك من 
منطلق أنه يقوم بتدعيم أركان البلاطات المصمته لمقاومة اجهادات اللى والقص التى تتعرض لها اركان البلاطه.مع الاخذ فى الاعتبار العوامل التاليه:

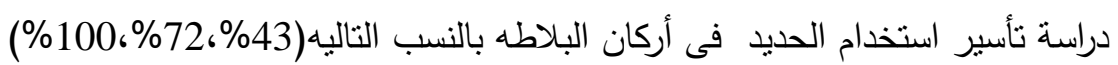

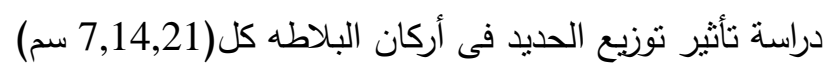
دراسة تأثير عرض وعمق الكمرات المحيطه.

وتتم دراسة تأثثر هذا الحديد القطرى على الازاحات والحمل الاقصى للبلاطه بإستخدام نظرية العناصر المحددة (3DFEM) مستخدماً برنامج (ANSYS)، وفيه تم تمثيل الخرسانه المسلحة بإستخدام

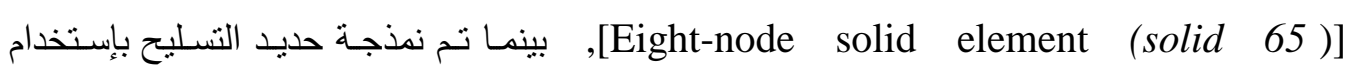
[three-dimensional spar element( $\operatorname{Link} 8)]$

\section{ويمكن تلخيص النتائج التى تم التوصل إليها من خلال الاراسه فيما بليح:}

وجود حديد فى أركان البلاطات ذات الاتجاهين يحسن من قيمة الحمل الاقصى للبلاطات

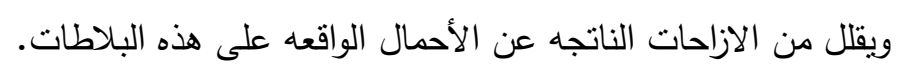

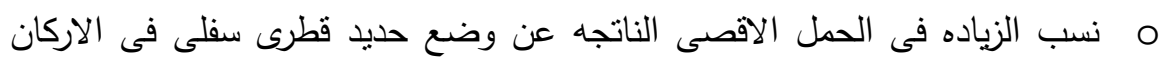
تصل الى(10\%) بينما تصل نسب التقليل فى الازاحات نتيجة هذا التسليح (30\%)

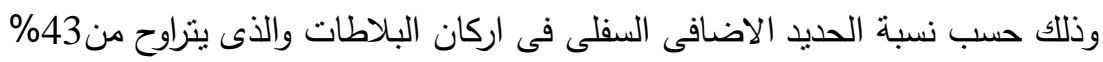

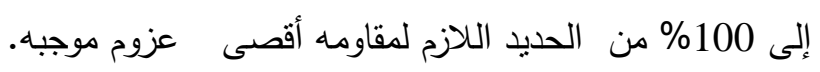

النسبه المتلى للحديد المستخدم فى أركان البلاطات العلوى والسفلى هى 100\% ويتم نوزيعها

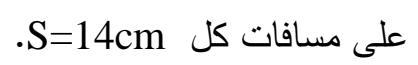
زيادة جساءة الكمرات المحيطه بالبلاطه بحسن من سلوك البلاطه فى زيادة الحمل الاقصى

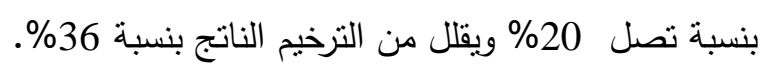

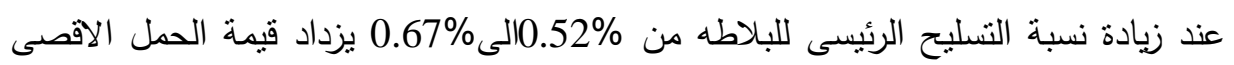
بنسبة7\% بينما عند تسليح اركان البلاطه بحديد علوى وسفلى بنسبة 100\% من من التسليح الرئيسى للبلاطه يزاد قيمة الحمل الاقصى بنسبة 10\%،مما يبين ان تسليح اركان البلاطه افضل من الناحيه الاقتصاديه فضلا عن ثاثيره على الحمل الاقصى للبلاطه. 